Original scientific article

UDC: $615.89(497.6) " 18 / 19 "$

DOI: $10.25106 / \mathrm{ahm} .2017 .2712$

Željko Dugac

Croatian Academy of Sciences and Arts

Institute for the History and Philosophy of Science

Division for the Philosophy of Science

Ante Kovačića 5, 10000 Zagreb, Croatia

E-mail: dugachazu@gmail.com

\title{
PHYSICIANS AS COLLECTORS OF FOLK MEDICINE RECORDS IN BOSNIA AND HERZEGOVINA AT THE END OF THE $19^{\mathrm{TH}}$ AND IN THE EARLY $20^{\mathrm{TH}}$ CENTURY
}

\begin{abstract}
The paper discusses the phenomena of collecting of folk medicine materials by physicians who worked in Bosnia and Herzegovina at the end of the 19th and early 20th centuries. These first physicians - ethnographers, along with their regular services in medical institutions, also begin collecting and recording data related to the folk's forms of treatment of different diseases, popular beliefs about the causes of disease and ways of protecting. Their observations are published in the Glasniku Zemaljskog Muzeja u Bosni i Hercegovini (Journal of the National Museum of Bosnia and Herzegovina). While on the one hand enthusiastically collecting data and material relics, thus endeavouring to preserve this part of the national culture, on the other hand, as representatives of the official medical system, challenge the value of the folk's treatment methods and want to replace them with, as they stated, more rational methods of official medicine. The paper focuses on the two periods of operation of the aforementioned physicians, one during the Austrian administration and the other during the Kingdom of Yugoslavia. Both periods are characterized by the interest of the physicians to the folk medicine, but also by their popular public education work, especially at the time of the Kingdom of Yugoslavia, in order to replace local folk healers with the medical professions and institutions who will be the only responsible for the issues of diagnosis and treatment of illness.
\end{abstract}

Keywords: folk medicine, history of medicine, ethnography Non MeSH: Bosna and Herzegovina 


\section{Introduction}

„Noting is stranger then this business of humans observing other humans in order to write about them." [1] noticed Ruth Behar, anthropologist and writer. His notice sounds so vivid when we talk about business of collecting folk medicine records in the field. Phenomenon of collection of folk medicine records on the territory of Bosnia and Herzegovina began with the arrival of physicians, mainly dispatched from the Austrian Monarchy's centre in Vienna, in the light of colonization of new territory in late $19^{\text {th }}$ century. It was connected with the similar process of collecting of unusual and new data interesting for $19^{\text {th }}$ century science. Some of this processes were undertaken by different sorts of intellectuals earlier in Croatia, particularly in the part of Dalmatia, where Austrian interest was specially focused [2]. After occupation of Bosnia and Herzegovina in 1878 many archaeologists, ethnographers, botanists, zoologist, as well as physicians started with collecting and recording folk medicine tradition as well as make a critical observation of customs they noticed. After this first wave of "explorer's colonisation", new physicians came to take some part of its research through the whole first part of the $20^{\text {th }}$ century. When health education on a large scale began in the Kingdom of Serbs, Croats and Slovenes after World War One has ended, the research of folk medicine was continued. In this paper I will try to point some controversies connected with this phenomenon. For more theoretical frame of the phenomenon compare [3-6].

The Austrian occupation and subsequent annexation of Bosnia and Herzegovina introduced a new medical system to the provinces that had been ruled by Ottomans for centuries. Medics were recruited from all over the Empire to occupy the newly established posts as hospital, district and municipality physicians. Whilst taking part in the modern medical organization and exploring endemic diseases and health conditions in rural areas, they came into contact and became fascinated with the culture strongly interweaved with old pagan beliefs as well as Islamic, Catholic, Orthodox and Judaic traditions. This unusual mixture formed the basis for folk customs that were integrative parts of everyday life, as well as a tradition that the sick were treated by people without medical training, by folk healers such as village women (called witch-doctors) and men, most commonly barbers - berberi, blacksmiths, priests and others. Franciscan monks, Muslim hodža and Eastern Orthodox priests were especially engaged in medical treatments in Bosnia and Herzegovina. The end of Balkan Wars and World War One announced the appearance of demobilized medical attendants, i.e. the men who have worked as semi-skilled assistants in medical corps during the war. After returning home most of them had combined new medical skills with traditional ways of healing, which made an unusual mixture. Village healers were very close to people and integrated in the village life, as they had lived with their fellow-villagers and shared the same destiny. In most cases they learned their craft by working side by side with their parents or other family members. They treated a variety of diseases and traumas, from those easily recognizable 
to the Western medicine, such as dislocated joints, fractured bones, tooth diseases, to those concerned with the removal of magical spells. According to folk perception, they also had significant role in protection against certain supernatural beings, such as witches and demons usually called džin and šejtan [7].

\section{Setting the stage: Austrian physicians arrive in Bosnia}

The National Museum of Bosnia and Herzegovina in Sarajevo, the capital of the new Austrian province, was opened as early as 1888 . It was a place where various arts and crafts collections were being gathered. In the following year, the Museum journal had been launched - Glasnik Zemaljskog Muzeja Bosne i Hercegovine (Journal of the National Museum of Bosnia and Herzegovina). Like other journals of that time, for example the Yugoslav's (today Croatian) Academy of Sciences and Arts Zbornik za narodni život i običaje Južnih Slavena (Journal of Folk Life and Customs of South Slavs), it also broadly studied the history and culture of the peoples in the region. Papers on archaeology, art history, general history and especially ethnographic records about specific customs and everyday folk life were published. The journal was a meeting place for intellectuals, many of whom were newcomers in Bosnia and Herzegovina. They included doctors who were obviously intrigued by folk medicine they encountered in their practical work.

Austrian skin and venereal diseases specialist Leopold Glück, who came to Bosnia to study endemic syphilis, was also unable to resist the strong temptation of folk medicine to which he paid a great deal of attention. He had observed different phenomena, including folk healing of rabies. In an article in Glasnik in 1893, he recorded a variety of hidden formulae and inscriptures used in folk medicine rituals [8]. In this volume, Sadik Ugljen wrote about lead as a folk remedy. In fact, it is a text about the ritual of putting hot lead in the water to specify the cause of some disease or fear. Ugljen also mentions that it is important to collect such a records as they still existed [9]. Doctor Josip Preindlsberger from the surgical-ophthalmological ward in the Hospital in Sarajevo published text on folk medicine in the same journal in 1900. He discussed the treatments of eye diseases by folk healers and the surgical operations of urinary calculi. The text was accompanied by pictures of a series of instruments used for that purpose, and as the main reason for publishing, the ethnographic, cultural and historic reasons were mentioned [10].

As Pletenac pointed in his research about transition, Eastern Europe entered into the identity of the West in a form of a living past. On the example of Morlaks and Fortis, Pletenac wrote how this heritage has to be guarded and, at the same time, needs to be eliminated as the civilizational deficit [3]. We can clearly see such concept on the example of folk medicine research of physician ethnographers. Karl Steiner, one of the doctors who arrived in Bosnia in 1903 gives us a typical view of physician who started to explore the folk medicine in the new province of the Habsburg Monarhy. Structured with medical and scientific background, Steiner tried to explored hidden folk traditions about the origin of diseases, healing praxis and rituals of, as 
he put it, people with child-like understanding. He wrote: "Inspired by stories and fairy tales and interwoven by a pure folk poetry is the life and death of a simple and plain people in the hills of Bosnia. For centuries, the beautiful book of nature laid open before them, but those big children could not read from it, and only its images in their eternal change could be grasped by their child-like understanding. These people thought that in the rustle of the mountain forest they heard some mysterious voices, in the thunder of avalanches and rumble of felled rocks they suspected battle-cries of evil demons..." [11].

Even though they were impressed by the tradition they had discovered, those early physicians-ethnographers tried to place all folk medicine phenomena within a frame they found comprehensible. For example, Leopold Glück denied the alleged success of certain healers in the treatment of rabies by concluding that those patients, who were allegedly cured by those persons, had not been bitten by a rabid dog in the first place. He claimed, instead, that they had been bitten by an animal which was hungry, thirsty and scared, and had only appeared to be rabid. Through their views we can recognize a mechanism used not only in Bosnia and Herzegovina, but in all European colonies where explores tried to collect and record something, but at the same time they also tried to give their own explanation. Finally, whether it was their wish or not, the underlying phenomenon was changed or destroyed. In those cases, folk medicine phenomena, although admirable, was interfered with and thus subjected to modification, regulation, explanation and extermination. The first physicians-ethnographers contradicted themselves, because, on the one hand, they had admired the phenomenon and wanted to record it, but on the other hand they also wanted to belittle and eradicate it.

Doctor Oscar Hloverka thought that healing methods in folk medicine based on superstition, or as he said, which cannot be counted in the area of common sense (sphere of spiritual), disappear as general culture and civilization evolve. He states that it is necessary to compile this data in order to examine the people ethnographically, because they will disappear in the future. Hloverka argued that everything that cannot be accepted by the official scientific medicine is condemned to ruin and disappearance [12]. All physician ethnographers of that time expressed the naïve thinking of $19^{\text {th }}$ century intellectuals that such concepts of healing will vanish in time with advance of science and positivism.

\section{Imposing old thinking on the new ways}

The formation of a new type of health organization and a completely new way of organizing public health after World War One placed folk practitioners and their methods of treatment in more or less the same position. The new public health system was organized by doctor Andrija Štampar, an important representative of social medicine on a global level. The new health system implied vigorous, intensive and comprehensive programme of health education within which a battle against 
quackery occupied a significant part. New public health doctrine thought that for the successful improvement of, as it was then usually called, "people's health", it was necessary to both study and teach the people. The study of people, their local characteristics and needs, which of course included folk medicine, was the basis for further work on health education. In that way, fighting quackery and installing doctors and nurses as central figures to which people could turn for help, became one of the main goals of the health education programmes. Folk medicine and folk healers were ridiculed and criticized in every imaginable way. They were referred to as persons of dubious morality, who cheated their fellow villagers and who only wanted to get money from them. Various advertising mechanisms popular at that time were used for that purpose, such as posters, leaflets, texts in magazines, and health propaganda films. I would especially like to stress the film laboratory in the School of Public Health in Zagreb, which was very active in the producing of different health propaganda movies. Most of them were connected with the quackery [13]. Serbian hygienist Milan Jovanović Batut, father of hygienic movement on the Balkans and teacher of Andrija Štampar, published a book in 1923 with significant title: Quack doctors - How they cheat the people: for the instruction of uninformed and naïve persons (NadrilekariKako varaju, globe i zatiru narod: neobaveštenom i lakovernom svetu za pouku) [14]. It is interesting that historians of medicine, who should have studied and recorded the phenomenon, were involved in this combat against quackery. Thus in 1936 the Croatian historian of medicine Vladimir Bazala published a book titled Self-proclaimed Physicians: Images from the History of Quackery (Samozvani liječnici: Slike iz povijesti nadriliječništva). It was dedicated to the history of folk medicine, but also to its current presence among South Slavs. Book is accompanied with the author's negative comments on folk practitioners [15]. As a historian of medicine with medical beckground, Basala, as many others, didn't respect the historiographic objectives and applied the typical statement of official medicine doctrine.

Quackery and its suppression was very lively discussed in the medical circles of the Kingdom of Yugoslavia. For instance, at the conference of the Yugoslav Association of Physicians in 1933, some physicians suggested undertaking drastic measures against folk medicine and its practitioners, such as: "Ruthless persecution of witchdoctors and all those involved in quackery, as well as those who seek their help..." [16]. Therefore, actions against quackery interweaved with almost all other public education themes, and there was virtually no segment of health propaganda in which they were not present. Medical science and its representatives were presented as the only authorities on health and diseases. Health education relied on explanation of the basic laws of science, physical, chemical and biological knowledge and the cause and effect principles. The sequence of deduction based on facts and critical thinking was emphasized $[15,13]$.

Medicine, physicians and nurses were strictly distanced from everything that had any magical or religious component. They were the representatives of pure reason, everything else was shameful and culpable. The phenomenon of folk medicine 
was above all interesting for its mechanisms and methods of its effects, which were investigated in order to be exposed and discredited later on. Indeed, some experiential methods, such as treatments with medicinal herbs, were recognized to some extent, but that therapeutic effect was anyway investigated and judged by science. The collection of folk objects, which also included the items used in folk medicine, was considered to have an exclusive museum value, and was used in museum collections and hygienic exhibitions. It possessed an educational value because it shown primitive folk medicine to the observer, suggesting that his attitude towards it should be negative [13].

\section{Collecting folk medicine data - coexistence without critics}

From late 1930s to late 1950s valuable informations and objects from folk medicine tradition was collected by doctor Stanko Sielski, who was the head of the Institute for the eradication of Syphilis in Banja Luka in the beginning of 1940s. Sielski later become a professor of the history of medicine in Sarajevo and a curator of the Museum for the History of Medicine of the Croatian Medical Association in Zagreb. Huserif Tahirović explored his work and life and he pointed a lot of important facts about this doctor. The especially encouraging was that he saved Jewish doctors, employees of the Institute where he worked, from persecution and deportation in concentration camps during the World War Two [17]. In addition to his medical and academic career, Sielski was a passionate collector of folk's relicts and great intellectual and humanist. His collection of different ethnographical objects became the basis of two folk medicine collections: one located today in the Ethnographic Museum in Zagreb and the other in the Croatian Academy of Sciences and Arts. Sielski collected archaeological finds as well. For example, an earring dated from the beginning of the $7^{\text {th }}$ century, which he had bought off a peasant in Velika Kladuša, Bosnia, later became an exhibit in the mediaeval collection of the Archaeological Museum in Zagreb. Sielski had collected and recorded folk medicine with the great respect and tolerance; we cannot find any trace where he makes any negative connotation on them.

The most interesting objects collected by Sielski are different amulets and talismans, made of silver and dated between the $17^{\text {th }}$ and the $20^{\text {th }}$ century. Amulets are usually made of metal, minerals, parts of plants or animals, paper and other materials; they were carried on the human body in the belief that they will provide protection against diseases and misfortune. Talismans are believed to bring health, happiness and well-being. These objects were used for protection against diseases in general, as well as for prevention and cure of particular diseases. Sielski also collected scriptures (zapisi), form of amulets, which were considered as protection against witchcraft. In the Muslim heritage, they were written on pieces of paper, quoting holy scripts, very often combined with mysterious formulae and numerical expressions. There were basic scriptures against any kind of misfortune, as well as 'specialized' ones used for particular diseases and conditions. Scriptures were laid onto an inflicted spot, or 
sometimes the sick man inhaled or drank the water in which the scriptures had been soaked. They were worn around neck, on the shoulder, above waist, near the body, sewn into clothes, etc. Poor people sewed them into a wax-cloth, while the wealthy placed them into silver caskets [7].

Mentioned object are witnesses of interlacing of different cultures and religious concepts. Scripture casket usually had a typical Western European floral stylization and usually coins from Dubrovnik were hanging on the chains. On one side of such coin there was Christ the King giving a blessing with his right hand and holding a globe in his left hand, surrounded by stars with the visible text: SALVS TVTA. Saint Blaise, the Roman Catholic saint protector of Dubrovnik, may also be seen with the mithras on his head on the back side of the coins. We can also recognise Turkish coins or Arabic inscriptions on the same caskets. In fact, on the Muslim amulets we can see the figure of Christ the King and St. Blaise or Jewish symbols such as David's star. They are the meeting point between the worlds of religion and magic, but also between the cultures and heritage of the East and the West, of Jewish, Christian and Muslim traditions and coexistence of the Christian, Muslim and Jewish people in Bosnia and Herzegovina [7].

\section{Conclusion}

The phenomenon of collecting ethnographic records on folk medicine in Bosnia and Herzegovina, which began with the arrival of physicians, was initially part of the general process of researching folk culture in the newly acquired territory for the Austria-Hungary. It was also a point of incorporation of the new territory into the uniform patterns of institutions and administration, as well as a sign of new domination of medicine and state. Those first efforts were characterized by the typical views of colonial time, whereby the inhabitants of the rural area, an exotic territory for European centres of power, were seen as big children with child-like understanding. These people preserved ancient legends through their stories, they were both likeable and repulsive in their simplicity and naiveté, and as such, they were the source of inspiration for the artists, adventurers, and of course physicians who are usually attracted by anything that diverts them from the everyday life in surgery. These people had to be adapted for the new time, new habits and commitments.

Those first physician-ethnographers in Bosnia were still under the romantic notions that there, on the European soil, they would find hitherto unknown beneficial and healing herbs, a new ipecacuanha, coca or quinine hidden in the hills of Bosnia and known only to folk herbalists who jealously treasured it. And as time passed by, the quest for that secret healing herb was becoming more hopeless. Cold scientific reason exposed folk healers; it washed away all the charm and mysticism from their concoctions and concluded that the majority of ingredients had been known for ages and had no spectacular effect.

After the World War One, the new state of South Slavs again took interest in folk medicine in Bosnia and Herzegovina, but for particularly different reasons. Namely, 
after the formation of the Ministry of Public Health, doctor Andrija Štampar, the head of the Hygiene Department and the author of the modern public health policy in the country, saw the collection of data on folk customs and folk medicine from another perspective. The collection of knowledge on folk traditions, or as it was called then "the studying of the people", had been reinitiated, but this time for the purpose of better, easier and more adequate instruction and education of that same people.

Stanko Sielski's collecting work was in some way different, not only because he collected the valuable number of important folk medicine objects, but also because he shown deep respect to this part of culture composed of unusual interlacing of symbols, beliefs and tolerance between Christian, Muslim and Jewish traditions. It was also not burdened with the official medical criticism and evaluation of folk medicine methods.

The study of folk medicine shows us its close connection with changes in the society, especially of the dominant trends in science, medicine and public health policy. As elsewhere through the Europe and the world, Bosnia and Hercegovina also became the territory on which strong forces of politics and medicine changed the image of traditional life and ways of health. The texts and objects of called physician-ethnographers are now a rare witnesses of some entirely forgotten folk medicine concepts of healing. On the other hand, the controversy that physicians would also like to introduce a completely new way of healing system as well a medicalization and modernisation of public health sector within official medical concept, caused that the main substrate of recording was catalysed to be vanished.

\section{Rezime}

Rad se bavi problematikom sakupljanja građe iz područja narodne medicine od strane liječnika koji dolaze raditi u Bosnu i Hercegovinu krajem XIX i početkom XX stoljeća. Ti prvi liječnici-etnografi uz svoju redovitu službu u medicinskim ustanovama započinju i sa sakupljanjem i bilježenjem podataka vezanih uz narodne oblike liječenja, narodna vjerovanja o uzrocima bolesti i načinima zaštite i liječenja, a svoja opažanja objavljuju u Glasniku Zemaljskog Muzeja u Bosni i Hercegovini (Journal of the National Museum of Bosnia and Herzegovina). I dok sa jedne strane entuzijastično prikupljaju podatke i materijalne relikte nastojeći na taj način sačuvat i taj dio narodne kulture, s druge strane, kao predstavnici službenog medicinskog sustava, osporavaju vrijednost narodnih metoda liječenja, te ih žele ukinuti i zamijeniti po njihovom mišljenju racionalnijim metodama službene medicine. $U$ radu se ističu dva razdoblja djelovanja navedenih liječnika, jedan za vrijeme austrijske uprave te drugi za vrijeme Kraljevine Jugoslavije. Oba su razdoblja okarakterizirana zanimanjem liječnika za narodnu medicinu ali i njihovim angažmanom, posebice u vrijeme Kraljevine Jugoslavije, da se zdravstvenim prosvjećivanjem suzbiju narodni iscjelitelji te medicinska struka i njezine institucije postave kao jedini i isključivo nadležni za pitanja otkrivanja i liječenja bolesti. 


\section{References:}

1. Behar R. The Vulnerable Observer: Anthropology that Breaks Your Heart. Boston: Beacon Press; 1996.

2. Pederin I. Jadranska Hrvatska u austrijskim i njemačkim putopisima [Adriatic Croatia in Austrian and German travelogues]. Zagreb: Nakladni zavod Matice hrvatske; 1991.

3. Pletenac T. Od Morlaka do postsocijalizma: Tranzicija kao element mimikrijskog diskursa [From Morlaks to postsocialism: Transition as an element of mimicry discourse]. In: Ribić V, Editor. Antropologija postsocijalizma. Beograd: Srpski genealoški centar; 2007.

4. Biti V. Pripitomljavanje drugog [The taming of other]. Zagreb: Hrvatsko filozofsko društvo; 1989.

5. Harrison F, editor. Decolonizing Anthropology: Moving Further toward an Anthropology for Liberation. Washington DC: American Anthropological Association. 1991.

6. Said WE. Representing the Colonized: Anthropology's Interlocutors. Critical Inquiry. 1989;15(2):205-25.

7. Brenko A, Dugac Ž, Randić M. Narodna medicina [Folk medicine]. Zagreb: Etnografski muzej; 2001.

8. Glik L. Narodno liječenje bjesnoće u Bosni i Hercegovini [The folk treatment of rabies in Bosnia and Herzegovina]. Glasnik zemaljskog muzeja u Bosni i Hercegovini. 1893;5:499-510.

9. Ugljen S. Olovo kao narodni lijek [Lead as a folk remedy]. Glasnik zemaljskog muzeja u Bosni i Hercegovini. 1893;5:168-70.

10. Preindlsberger J. Prilozi narodnoj medicine iz Bosne [Contributions to folk medicine from Bosnia]. Glasnik zemaljskog muzeja u Bosni i Hercegovini. 1900;12:65-81.

11. Steiner K. Bosanska narodna medicina [Bosnian folk medicine]. Glasnik zemaljskog muzeja u Bosni i Hercegovini. 1903;15:563-79.

12. Hoverka O. Narodna medicina na poluotoku Pelješcu u Dalmaciji [Folk medicine on Pelješac peninsula in Dalmatia]. Glasnik zemaljskog muzeja u Bosni i Hercegovini. 1900;12:119-54.

13. 13. Dugac Ž. Kako biti čist i zdrav: Zdravstveno prosvjećivanje u međuratnoj Hrvatskoj [How to be clean and healthy: Health education in interwar Croatia]. Zagreb: Srednja Europa; 2010.

14. 14. Jovanović-Batut M. Nadrilekari: kako varaju, globe i zatiru narod: neobaveštenom i lakovernom svetu za pouku [Quack doctors - How they cheat the people: for the instruction of uninformed and naïve persons]. Beograd: Ministarstvo narodnog zdravlja; 1923.

15. 15. Bazala V. Samozvani liječnici: Slike iz povijesti nadriliječništva [Self-proclaimed Physicians: Images from the History of Quackery]. Zagreb: Škola narodnog zdravlja; 1936.

16. 16. Barać J. Metode zdravstvene propagande [Methods of health propaganda]. Lijec Vjesn. 1920;42:456-58.

17. Tahirović H. Dr. Stanko Sielski (1891-1958): Physician, scientist, humanist. Acta Med Acad. 2015;44(2):169-80.

Submitted: 11. 12. 2017.

Reviwed: 19. 12. 2017.

Accepted: 27. 12. 2017. 